\title{
Eldre med dårlig helse har lave vitamin D-nivåer
}

Lavt vitamin D-nivå er forbundet med $\varnothing$ kt risiko for hoftebrudd,

hjerteinfarkt, kreft eller død. Assosiasjonen varierer med årstiden.

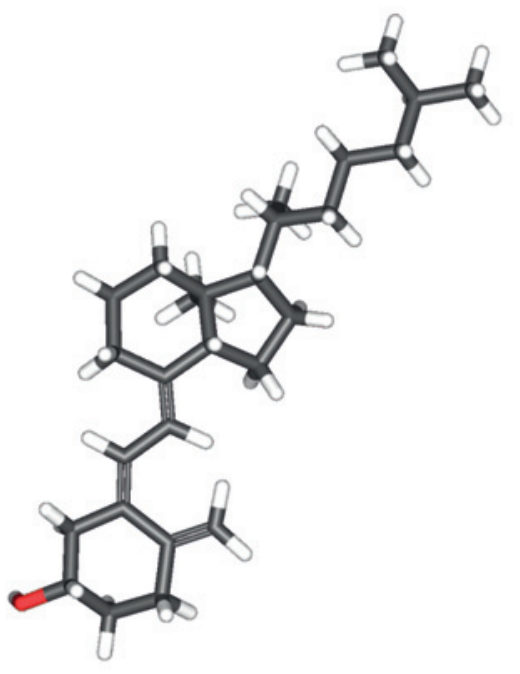

Illustrasjonsfoto Wikimedia Commons
Vitamin D har mange biologiske funksjoner. Lavt vitamin D-nivå øker risikoen for dårlig beinhelse, kanskje også for koronar hjertesykdom og kreft.

I en amerikansk studie ble 1621 eldre hvite personer fulgt $\mathrm{i}$ median 11 år (1). Nivået av 25-hydroksyvitamin D ved studiestart varierte med årstiden - det var lavest om vinteren og høyest om sommeren. Lavt vitamin D-nivå om vinteren var vanligst hos kvinner og hos dem med bosted nord i USA og var forbundet med høy kroppsmasseindeks, hypertensjon, lav fysisk aktivitet og høyt parathormonnivå. Lavt vitamin D-nivå var forbundet med forekomst av hoftebrudd, hjerteinfarkt, kreft eller død i løpet av studieperioden, men assosiasjonen varierte med årstiden da målingen ble gjort. En $24 \%$ høyere risiko ble funnet for vitamin D-nivåer under $43 \mathrm{nmol} / 1,50 \mathrm{nmol} / \mathrm{l}$, $61 \mathrm{nmol} / \log 55 \mathrm{nmol} / 1$ for henholdsvis vinter, vår, sommer og høst.

- I denne prospektive observasjonsstudien brukes et klinisk relevant endepunkt, ikke bare risikomarkører for sykdom, sier professor Haakon Meyer ved Avdeling for samfunnsmedisin, Universitetet i Oslo, og Nasjonalt folkehelseinstitutt. - Studien støt- ter anbefalinger om $50 \mathrm{nmol} / 1$ som nedre grense for vitamin D-nivå. Dette er i samsvar med gjeldende norske anbefalinger. Noen forskere anbefaler en høyere grense, men fortsatt er kunnskapsgrunnlaget for dette svakt, sier Meyer.

- I en svensk studie (2) ble det påvist høyere dødelighet hos eldre menn med lave og med svært høye vitamin D-nivåer, påpeker Meyer. - Høydosebehandling med vitamin D bør derfor prøves ut i randomiserte studier før dette eventuelt kan anbefales som forebyggende behandling, sier han.

\section{Petter Gjersvik \\ petter.gjersvik@gmail.com \\ Tidsskriftet \\ Litteratur \\ 1. de Boer $\mid \mathrm{H}$, Levin $\mathrm{G}$, Robinson-Cohen $\mathrm{C}$ et al. \\ Serum 25-hydroxyvitamin d concentration and risk for major clinical disease events in a community- based population of older adults: a cohort study. Ann Intern Med 2012; 156: 627-34. \\ 2. Michaëlsson K, Baron JA, Snellman $G$ et al. Plasma vitamin $D$ and mortality in older men: a community-based prospective cohort study. Am J Clin Nutr 2010; 92: 841-8.}

\section{Revaskularisering ved koronarsykdom}

\author{
Registerdata kan ikke gi sikre svar på om perkutan koronar interven- \\ sjon er bedre enn bypassoperasjon ved koronar hjertesykdom.
}

I en amerikansk studie ble data fra to store registre koblet for å gjøre en ikke-randomisert sammenlikning av utfall etter perkutan koronar intervensjon (PCI) og aortokoronar bypassoperasjon (ACB) (1). Pasienter $\geq 65$ år med tokars- eller trekarssykdom uten akutt hjerteinfarkt som var behandlet med enten perkutan koronar intervensjon $(\mathrm{n}=86244)$ eller aortokoronar bypassoperasjon $(n=103549)$ ble inkludert. Median oppfølgingstid var 2,7 år. Det var ingen signifikant forskjell i overlevelse etter ett år. Etter fire år var mortaliteten etter aortokoronar bypassoperasjon lavere enn mortaliteten etter perkutan koronar intervensjon.

- I utgangspunktet var gruppene svært ulike, blant annet når det gjaldt alderssammensetning, kjønnsfordeling, komorbiditet og forekomst av trekarssykdom, sier seniorkonsulent dr.med. Jan Erik Otterstad ved Senter for hjerteforskning, Sykehuset i Vestfold. - Selv med avanserte justeringsanalyser erkjenner forfatterne muligheten for seleksjon og ukjente faktorer som kan ha hatt innflytelse på resultatene. Konfunderende faktorer kan forklare forskjellen i mortalitet.
I en ledsagende lederartikkel påpekes det at observasjonsstudier ikke kan erstatte randomiserte, kontrollerte studier (2). Likevel gir det store antallet pasienter i denne studien styrke.

- Observasjonsstudier gir detaljer om hvordan og hvem som făr behandling og hvordan seleksjonen av pasienter varierer mellom behandlingsgruppene, sier han. - Dette er en interessant studie med store tall, men med selekterte pasienter og ukjente konfunderende faktorer. Resultatene kan derfor ikke anses som representative for effekten på dødeligheten etter perkutan koronar intervensjon versus aortokoronar bypassoperasjon $\mathrm{i}$ en generell pasientpopulasjon, sier Otterstad.

\section{Merete Kile Holtermann}

merete.holtermann@legeforeningen.no

Tidsskriftet

\footnotetext{
Litteratur

1. Weintraub WS, Grau-Sepulveda MV, Weiss JM et al. Comparative effectiveness of revascularization strategies. N Engl J Med 2012; 366: 1467-76.

2. Mauri L. Why we still need randomized trials to compare effectiveness. N Engl J Med 2012; 366: $1538-40$.
}

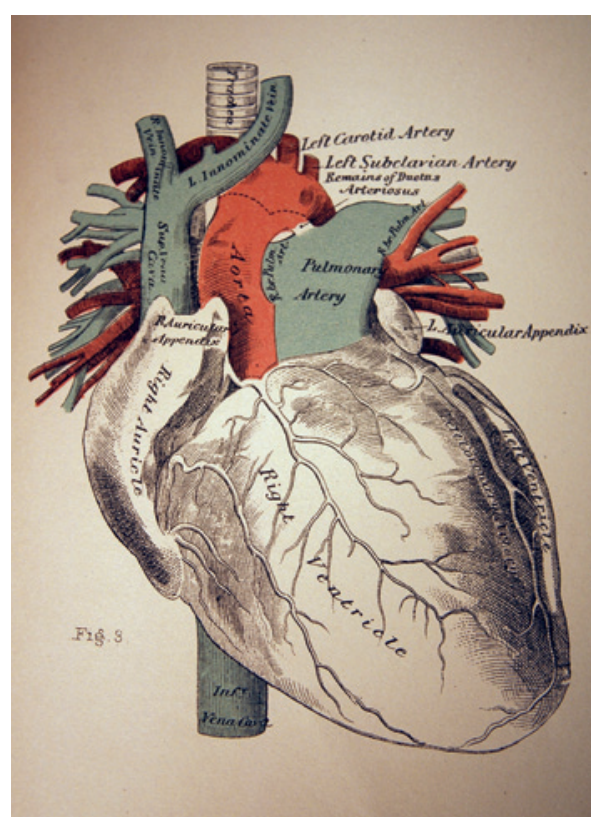

Illustrasjonsfoto thinkstockphoto 